Original Research Paper

\title{
The Comparison of RT-LAMP, RT-PCR and Dot-Blot Hybridization for Detection of Jembrana Disease Virus
}

\author{
${ }^{1,2}$ Asmarani Kusumawati, ${ }^{3}$ Tenri A. Wanahari, ${ }^{2}$ Issabellina D. Tampubolon and ${ }^{3}$ Basofi A. Mappakaya \\ ${ }^{I}$ Departement of Reproduction, Faculty of Veterinary Medicine, \\ Gadjah Mada University, Jalan Fauna no. 2, Yogyakarta, 55281 Indonesia \\ ${ }^{2}$ Centre of Biotechnology Study, Gadjah Mada University, Jalan Teknika Utara, Yogyakarta, 55281 Indonesia \\ ${ }^{3}$ Faculty of Medicine, Sebelas Maret University, Jalan Ir. Sutami 36 A, Surakarta, 57126 Indonesia
}

Article history

Received: 19-05-2015

Revised: 19-06-2015

Accepted: 22-06-2015

Corresponding Author:

Asmarani Kusumawati

Departement of Reproduction,

Faculty of Veterinary Medicine

Gadjah Mada University, Jalan

Fauna no. 2, Yogyakarta, 55281

Indonesia

Tel: +6281328867709 ;

$+6274560863$

Fax: +6274560863

Email: kartapati_2008@yahoo.com

\begin{abstract}
Jembrana disease virus is a viral pathogen that causes Jembrana disease in Bali cattle (Bos javanicus) with high mortality rate. Infection of Jembrana Disease Virus (JDV) on Bali cattle have caused substantial economic losses for farmers in Indonesia and Australia. In order to control the spread, development of a sensitive detection method is important. In this study, we used three different detection methods based on genomic approach, i.e., reverse transcriptase-polymerase chain reaction (RT-PCR), reverse transcriptase-loop mediated isothermal amplification (RT-LAMP) and dot-blot hybridization to detect JDV. Utilization of pGEX-TM, a recombinant plasmid containing env-tm gene as a positive control showed that RT-LAMP is the most sensitive method compares the two others. It could detect template concentration as low as $10^{-6} \mathrm{ng} \mu \mathrm{L}^{-1}$ or equivalent to $1.52 \times 10^{2}$ plasmid copy number, 100 and 10000 more sensitive than RTPCR and dot-blot hybridization, respectively.
\end{abstract}

Keywords: Jembrana Disease, RT-PCR, RT-LAMP, dot-blot hybridization, Comparative Analysis

\section{Introduction}

Jembrana Disease Virus (JDV) is a lentivirus associated with an acute disease syndrome on Bali cattle (Bos javanicus) in Indonesia and Australia (Kusumawati et al., 2014a). After short latent period, infected cattle show clinical signs of fever, lymphadenopathy and lymphopenia, at which stage high viral titres of $10^{8}$ infectious units $/ \mathrm{mL}$ are found in the plasma (Kusumawati et al., 2014b; Soeharsono et al., 1990; Soesanto et al., 1990). In fatal infection, death is attributed to multisystem involvement. In non-fatal infection, regression of lesions commences about 5 weeks post-infection and the recovered cattle is resistant to further development of clinical disease (Dharma et al., 1991). A recovered cattle will develop a delayed immune respone to the same or different isolates of JDV but still in state of viraemia with no recurrence for at least 2 years after infection (Kusumawati et al., 2014b). A carrier cattle is a potential source of infection. The etiology of the disease and the mode of transmission in nature are as yet unknown but the disease can be readily transmitted to susceptible cattle by the exposure of blood, spleen, or lymph node material from infected cattle (Soeharsono et al., 1990; Kusumawati et al., 2014b). The disease have been spread to several islands in Indonesia such as Sumatra and Kalimantan and it is believed occurred via the distribution of carrier cattle (Kusumawati et al., 2014b).

In order to control the spread of JDV infection, development of a sensitive detection method is important. Furthermore, the method used has to give accurate result because it is known there is a possibility to cross react with another bovine lentivirus i.e., Bovine Immunodeficiency Virus (BIV) since BIV was genetically and antigenically the most closely related to JDV although the respective associated disease is quite different (Kusumawati et al., 2014a). In this study, we describe the comparison of genomic based-method of reverse transcriptase-polymerase chain reaction (RTPCR), reverse transcriptase-loop mediated isothermal amplification (RT-LAMP) and dot-blot hybridization to detect JDV genomic material. Those methods are commonly used in detecting for many infectious diseases (Kusumawati et al., 2014c; Parida et al., 2008). RT-PCR and RT-LAMP work by amplifying the genomic material until sufficient amount of amplicons can be detected by electrophoresis (Notomi et al., 2000; Parida et al., 2008), while dot-blot hybridization works by using spesific probe which hybridize to certain genomic material 
(Kusumawati et al., 2014c). The aim of this study is to compare the sensitivity among all of the three methods.

\section{Materials and Methods}

\section{Sample and Material Preparation}

Whole blood samples were obtained from carrier cattle on several livestocks in South Kalimantan, Indonesia. Each sample was collected in $5 \mathrm{~mL}$ EDTA $\mathrm{K} 2 / \mathrm{K} 3$ blood collection tube and storaged in $4^{\circ} \mathrm{C}$ until it was used. In this study, we used pGEX-TM, a recombinant plasmid containing JDV env-tm gene for positive control. All used glasswares were treated with $0.1 \%$ Diethyl Pyrocarbonate in water overnight $(12 \mathrm{~h})$ at $37^{\circ} \mathrm{C}$ and then autoclaved or heated to $100^{\circ} \mathrm{C}$ for $15 \mathrm{~min}$.

\section{RNA Viral and Positive Control Sample Preparation}

RNA viral was extracted with High Pure Viral Nucleid Acid Kit $\left(\right.$ Roche $\left.^{\circledR}\right)$, following the manufacturer's instructions. pGEX-TM was obtained from previous study (Kusumawati et al., 2010), propagated in Luria Bertani liquid medium and extracted with GenJet Plasmid Miniprep Kit (Fermentas), following the manufacturer's instructions. RNA and pGEX-TM concentration and quality were also measured by spectrophotometric analysis at 260 and $280 \mathrm{~nm}$. Each RNA sample from whole blood extraction and pGEX$\mathrm{TM}$ was prepared in $10 \mathrm{ng} \mu \mathrm{L}^{-1}$ concentration. They were then diluted with double-distilled $\mathrm{H}_{2} \mathrm{O}$ RNAse free in a series of 10 -fold dilution and used as a template for PCR and LAMP detection.

\section{Detection by Polymerase Chain Reaction (PCR)}

DNA synthesis from each RNA sample was performed in a $25 \mu \mathrm{L}$ reaction volume containing 6.75 $\mu \mathrm{L}$ of RNA and $5 \mu \mathrm{M}$ of B3 primer. RNA mixture was warmed $70^{\circ} \mathrm{C}$ for $10 \mathrm{~min}(\mathrm{~min})$ and cooled in ice water for $5 \mathrm{~min}$. A mixture containing $10 \mathrm{mM}$ of dNTP mix (Bioron, Germany), 7.5U of AMV reverse transcriptase (Promega), 1x of AMV reaction buffer, 4U of Protector RNAse Inhibitor (Roche, Germany) and nuclease free water was added to RNA mixture. The mixture was incubated at $37^{\circ} \mathrm{C}$ for $60 \mathrm{~min}$ and terminated at $95^{\circ} \mathrm{C}$ for 2 min using waterbath (Haake L).

The detection by PCR assay was performed using a DreamTaq ${ }^{\mathrm{TM}}$ Green PCR Master Mix $2 \mathrm{X}$ in a $25 \mu \mathrm{L}$ reaction volume. The mixture consist of $2 \mu \mathrm{L}$ each of sample (cDNA or pGEX-TM), $12.5 \mu \mathrm{L}$ of PCR master mix, $5 \mu \mathrm{M}$ each of $\mathrm{F} 3$ and $\mathrm{B} 3$ primer and nuclease free water. The amplification program was performed as follows: Initial denaturation at $95^{\circ} \mathrm{C}$ for $5 \mathrm{~min}$, followed by 30 cycles at $95^{\circ} \mathrm{C}$ for $45(\mathrm{sec}), 58^{\circ} \mathrm{C}$ for $30 \mathrm{sec} ; 72^{\circ} \mathrm{C}$ for $45 \mathrm{sec}$ and then a terminal extention step of $72^{\circ} \mathrm{C}$ for $10 \mathrm{~min} .5 \mu \mathrm{L}$ of PCR products then were electrophoresed on $1.8 \%$ agarose gel to verify the presence of the expected $211 \mathrm{bp}$ band target.

\section{Detection by Loop-Mediated Isothermal Amplification (LAMP)}

LAMP reaction mixture consist of $1,8 \mu \mathrm{M}$ each of FIP and BIP primer, $0.2 \mu \mathrm{M}$ each of $\mathrm{F} 3$ and $\mathrm{B} 3$ primer, $1.2 \mathrm{mM}$ of dNTP mix, 0.6 M betaine, $10 \mathrm{mM} \mathrm{MgSO} 4,8 \mathrm{U}$ of Bst DNA polymerase, $1 \mathrm{x}$ of Bst DNA polymerase reaction buffer and $1 \mu \mathrm{L}$ each of sample (pGEX-TM or RNA). For RNA sample, $0.125 \mathrm{U}$ of AMV reverse transcriptase and $4 \mathrm{U}$ of Protector RNAse Inhibitor were added on the LAMP reaction mixture. Both LAMP and RT-LAMP was performed in a $25 \mu \mathrm{L}$ reaction volume, incubated at $60^{\circ} \mathrm{C}$ for $1(\mathrm{~h})$ and terminated at $80^{\circ} \mathrm{C}$ for $4 \mathrm{~min}$.

\section{Probe Preparation of Dot-Blot Hybridization}

Linearized pGEX-TM was used as a template for probe synthesizing with PCR DIG Labeling Mix (Roche $($ ). According to the manufacturer's instructions, reaction was performed in $50 \mu \mathrm{L}$ containing $5 \mathrm{ng}$ pGEXTM, PCR DIG labelling mix $(200 \mu \mathrm{M}$ dNTP, digoxigenine-11-dUTP) (1 uL), 1-5 U Taq DNA polymerase and 50 pmol each of $\mathrm{F} 3$ and $\mathrm{B} 3$ primer. PCR program was performed as "PCR detection method".

Quantification of probe was performed using DIG Quantification Teststrips (Roche). Probes were diluted to obtain $1 \mathrm{ng} \mu \mathrm{L}^{-1}$ final concentration. $1 \mathrm{uL}$ of diluted probe were blotted into membrane DIG Quantification Teststrips (Roche), dried for $2 \mathrm{~min}$, blocked into blocking solution for $2 \mathrm{~min}$, dipped into antibody solution for $3 \mathrm{~min}$ and blocked again into blocking solution for $1 \mathrm{~min}$. The strips then was washed with washing buffer for $1 \mathrm{~min}$, dipped into detection buffer for $1 \mathrm{~min}$ and finally incubated in color-substrate solution (NBT/BCIP) for 5-30 min. The color signal produced then compared to control quantification on the kit (Roche).

\section{Detection by Dot-Blot Hybridization}

RNA was diluted into $10 \mathrm{ng} \mu \mathrm{L}^{-1}, 1 \mathrm{ng} \mu \mathrm{L}^{-1}, 100 \mathrm{pg}$ $\mu \mathrm{L}^{-1}, 10 \mathrm{pg} \mu \mathrm{L}^{-1}$. Each of sample was denaturated in MOPS buffer, $50 \%$ formamide and $2 \mathrm{M}$ formaldehyde at $65^{\circ} \mathrm{C}$ for $5 \mathrm{~min}$ and then placed into ice tube. $1 \mu \mathrm{L}$ of denatured sample was immobilized on nylon Hybond-N membrane (Amersham Pharmacia). Membrane was dried at $50^{\circ} \mathrm{C}$ for $1 \mathrm{~h}$ then crosslinked by UV crosslinker for $5 \mathrm{~min}$.

Prehybridization was carried out at $42^{\circ} \mathrm{C}$ for $3-4 \mathrm{~h}$ in prehybridization medium (buffer $50 \%$ formamide, $2 \mathrm{X}$ $\mathrm{SSC}, 50 \mathrm{mM}$ sodium phosphate, $2 \%$ blocking reagent, $0,1 \%$ sodium sarkosyl, $7 \%$ SDS), followed hybridization by added $25 \mathrm{ng} \mathrm{mL}^{-1}$ of DIG labeled probe which had been denaturated at $100^{\circ} \mathrm{C}$ for $10 \mathrm{~min}$ in prehybridization medium. Hybridization was carried out at $45^{\circ} \mathrm{C}$ overnight. After hybridization, membrane was washed twice with $2 \mathrm{X}$ SSC and $0,1 \%$ SDS at room temperature for $15 \mathrm{~min}$ and $0,5 \mathrm{X}$ SSC and $0,1 \% \mathrm{SDS}$, at $68^{\circ} \mathrm{C}$ for $15 \mathrm{~min}$. Hybridization was detected with alkaline phosphataseconjugated and anti-DIGoxigenin antibody according to the manufacturer's instruction by washed the 
hybridization membrane with washing buffer I (100 mM maleic acid, $150 \mathrm{mM} \mathrm{NaCl} \mathrm{pH} 7.5,0.320$ ) for $1-3 \mathrm{~min}$, blocked into blocking reagent $(100 \mathrm{mM}$ maleic acid, 150 $\mathrm{mM} \mathrm{NaCl}, \mathrm{pH} 7,5,1 \%$ blocking reagent) for $1 \mathrm{~h}$, washed twice with washing buffer I for $15 \mathrm{~min}$ and wash once with washing buffer II (100 mM Tris-HCl, pH 9,5, 100 $\mathrm{mM} \mathrm{NaCl}, 50 \mathrm{mM} \mathrm{MgCl} 2$ ) for $15 \mathrm{~min}$. The process was continued by incubation of the membrane into $2 \mathrm{~mL}$ buffer II containing $7 \mu \mathrm{L}$ Nitro Blue Tetrazolium (NBT) dan $7 \mu \mathrm{L}$ solution 5-Bromo-4-Chloro-3-indolylphosphate (BCIP) (Sigma) in dark room for $2 \mathrm{~h}$ to overnight.

\section{Results}

The sensitivity of RT-PCR and LAMP assay were evaluated by using serial 10 -fold dilutions of pGEX-TM as

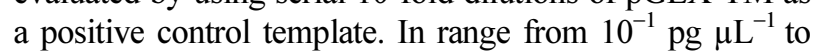

$10^{-2}$ fg $\mu \mathrm{L}^{-} 1$, PCR products were analysed using electrophoresis on agarose gel showed the presence of the expected $211 \mathrm{bp}$ band target up to concentration $10^{-1} \mathrm{pg}$ $\mu \mathrm{L}^{-1}$ or equivalent to $1.52 \times 10^{4}$ plasmid copy number (Fig. 1a). RT-LAMP products were also analysed using electrophoresis on agarose gel (DNA ladder like pattern result), ranging from $1 \mathrm{fg} \mathrm{uL}^{-1}$ to $10^{-2} \mathrm{fg} \mathrm{uL}^{-1}$. As shown in Fig. 1b, RT-LAMP was able to detect env-tm gene till dillution which contained $1 \mathrm{fg} \mathrm{uL}^{-1}$ of template or equivalent to $1.52 \times 10^{2}$ plasmid copy number. The sensitivity of dot-blot hybridization was evaluated on different concentration of RNA sample, i.e., $1 \mathrm{ng} \mathrm{uL}^{-1}$, $100 \mathrm{pg} \mathrm{uL}^{-1}$ and $10 \mathrm{pg} \mathrm{uL}^{-1}$. From five samples (Fig. $1 \mathrm{c}$ ), probe could detect up to $10 \mathrm{pg} \mu \mathrm{L}^{-1}$ for positive control sample (pGEX-TM) and up to concentration $100 \mathrm{pg} \mathrm{uL}^{-1}$ for RNA sample.

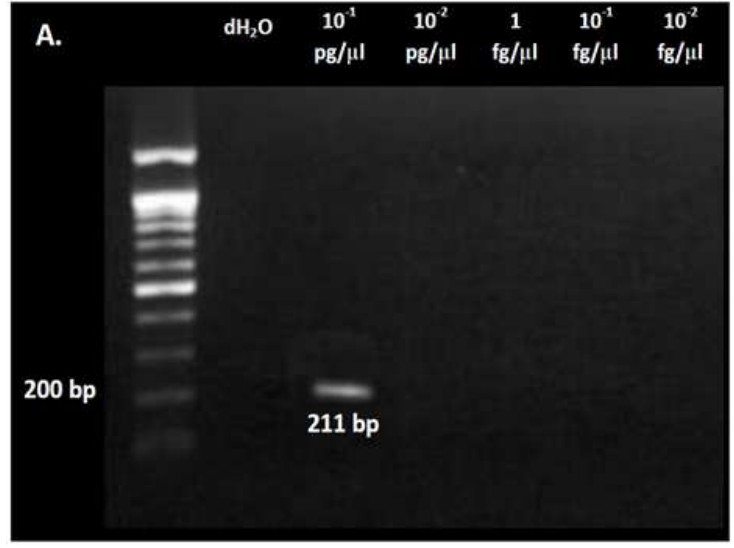

(a)

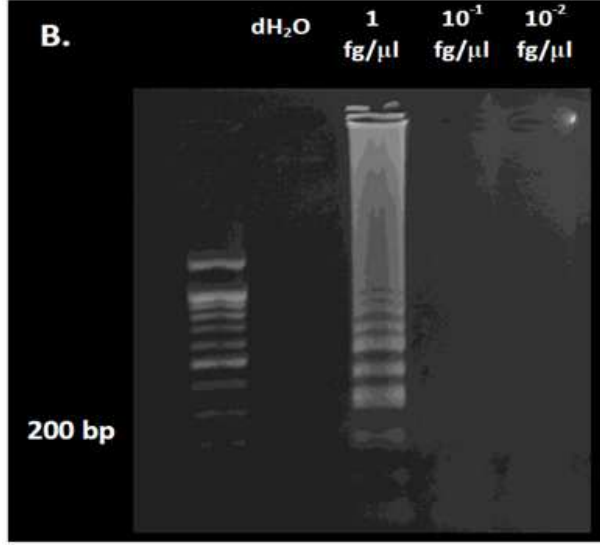

(b)

C. $\begin{array}{ccc}1 & 100 & 10 \\ \mathrm{ng} / \mu 1 & \mathrm{pg} / \mu 1 & \mathrm{pg} / \mu 1\end{array}$

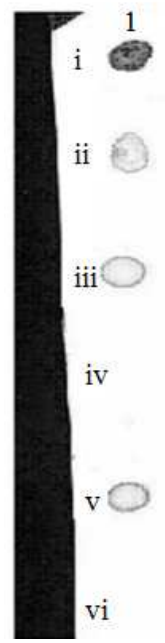

(c)

Fig. 1. Comparison of sensitivity of three molecular methods. Electrophoresis on $1.8 \%$ agarose gel of RT-PCR (a) and RT-LAMP (b) reaction products and probe hybridization on DIG quantification membrane of dot-blot hybridization (c). Serial 10-fold dilutions of

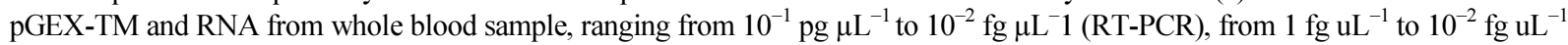
(RT-LAMP) and different concentration of five (RNA) samples, i.e., $1 \mathrm{ng} \mathrm{uL}^{-1}, 100 \mathrm{pg} \mathrm{uL}^{-1}$ and $10 \mathrm{pg} \mathrm{uL}^{-1}$ (dot-blot hybridization) 


\section{Discussion}

The aim of this study is to compare the sensitivity among RT-PCR, RT-LAMP and dot-blot hybridization. Infection of Jembrana disease virus on Bali cattle have caused substantial economic losses for farmers in Indonesia and Australia (Kusumawati et al., 2014a). JDV has spread to almost west region in Indonesia (Soeharsono et al., 1995; Burkala et al., 1999) and has high prevalence which is more than $50 \%$ (Kusumawati et al., 2014b). Therefore it is very important to identify the presence of the virus as early as possible to prevent further disease transmission among the Bali cattle or outbreak to other areas. Immunodiagnostic method based on host humoral response can not be used in early stages of the disease as like the other lentiviruses, JDV infection induces a delayed humoral response and JDV-specific antibodies are not produced in most infected cattle untill 11 weeks post infection (Kusumawati et al., 2014b). Furthermore, antibody-based diagnostic methods do not enable to distinguish JDV-from BIV-infection as the two bovine lentiviruses are antigenically very closely related (Kusumawati et al., 2014a). Distinguishing BIVinfection was only made feasible by using a BIV-specific monoclonal antibody that only recognizes the unique BIV gag epitope, which is not shared by JDV (Kusumawati et al., 2014a). During the acute phase, high titre of infectious JDV viral particles is found in plasma. Viruses are also abundantly present in secreted fluids, i.e., milk and saliva (Kusumawati et al., 2014b). In this case, detection method based on genomic approach is an appropriate method because of its ability to detect JDV in acute phase of the disease. In this study, we described three kind of molecular methods, i.e., RT-PCR, RTLAMP and dot-blot Hybridization and compared them to each other in term of their sensitivity.

In this study, the comparison of both RT- LAMP and PCR result assumed that RT-LAMP is 100 times more sensitive than PCR assay (comparison of sensitivity of RT-LAMP and PCR are, $1 \mathrm{fg} \mathrm{uL}^{-1}$ and $10^{-1} \mathrm{pg}$ $\mu \mathrm{L}^{-1}$, respectively). The application of both method on RNA sample give the same results as the positive control sample. Quantification of labeling probe showed that probe could detected up to concentration of $3 \mathrm{pg} \mathrm{uL^{-1 }}$ (data not shown). Based on the dot comparison between probe and the standard of the Roche $\AA$, it was obtained that probe have a high labeling efficiency. This information then used to determine the amount of probe in hybridization process. In other case, the comparison of both RT-LAMP and dot-blot hybridization shows that RT-LAMP is 10000 times more sensitive than dot-blot hybridization assay (comparison of sensitivity of RTAMP and dot-blot hybridization are, $1 \mathrm{fg} \mathrm{uL}^{-1}$ and $10 \mathrm{pg}$ $\mu \mathrm{L}^{-1}$, respectively). Theoretically, the sensitivity of
LAMP is due to the methodology is based on the high strand displacement activity of the polymerase used, allowing amplification reactions to produce more amount of DNA (Notomi et al., 2000). LAMP method is also known to be has high specificity due to the utilization of 2 or 3 primer pairs in the process (Notomi et al., 2000). LAMP is also a rapid analysis method which is due to there is no time losses during the process because of temperature changing as in PCR (Parida et al., 2008). LAMP is easy to perform and does not require expensive equipments or high technical skill. It is simple procedure on isotermal temperature, which can carried out on a simple waterbath, make this method is appropriate to be applied in field condition which has minimal facility, replaces PCR as the common method for detection purpose. Dot-blot hybridization generate specific results because of utilization of specific probes but this method is time consuming and very laborious (Kusumawati et al., 2014c).

\section{Conclusion}

Infection of JDV on Bali cattle have caused substantial economic losses for farmers in Indonesia and Australia. In order to control the spread, development of a sensitive detection method is important. In this study, we used three different detection methods based on genomic/molecular approach, i.e., RT-PCR, RT-LAMP and dot-blot hybridization to detect JDV genomic material. Utilization of pGEX-TM, a recombinant plasmid containing env-tm gene as a positive control showed that RT-LAMP is the most sensitive method compares the two others. It could detect template concentration as low as $10^{-6} \mathrm{ng} \mu \mathrm{L}^{-1}$ or equivalent to $1.52 \times 10^{2}$ plasmid copy number, 100 and 10000 more sensitive than RT-PCR and dot-blot hybridization, respectively.

\section{Acknowkledgment}

We acknowledged to Narendra Yoga Hendarta for provided the technical help and other general support.

\section{Funding Information}

This work was partly funded by a grant from Directorate General of Higher Education (DIKTI), Ministry of Education and Culture of Indonesia.

\section{Author's Contribution}

Asmarani Kusumawati: Participated in all experiments, aquisition of data, analyzed all the data and contributed to the writing of the manuscript, provided technical guidance, coordinated the writing of the manuscript, designed the research plan and organized the study. 
Tenri Ashari Wanahari: Participated in all experiments, aquisition of data, analyzed all the data and contributed to the writing of the manuscript.

Issabelina Dwades Tampubolon: Participated in all experiments, aquisition of data, analyzed all the data and contributed to the writing of the manuscript.

Basofi Ashari Mappakaya: Participated in interpretation of data and writing of the manuscript.

\section{Ethics}

This study was approved by Research Ethics Commitee, Faculty of Veterinary Medicine, Gadjah Mada University, Indonesia.

\section{References}

Burkala, E.J., T.M. Ellis, V. Voigt and G.E. Wilcox, 1999. Serological evidence of an Australian bovine lentivirus. Vet. Microbiol., 68: 171-177. PMID: 10501174

Dharma, D.M.N., A. Budiantono, R.S.F. Campbell and P.W. Ladds, 1991. Studies on experimental jembrana disease in bali cattle. III. Pathology. J. Comp. Pathol., 105: 397-414. PMID: 1663137

Kusumawati, A., R. Pratiwi, P. Astuti and P.H. Hamid, 2010. Characterization of envelope-transmembrane Gene of Jembrana Disease Virus Tabanan 1995 Iso. Indo. J. Biotechnol., 15: 15-19.

Kusumawati, A., T.A. Wanahari, R.F. Putri, B.A. Mappakaya and I.D. Tampubolon, 2014a. The structure and function of Jembrana disease virus genome. J. Inf. Mol. Biol. Sci., 2: 26-29. DOI: $10.14737 /$ jimb.2307-5465/2.2.26.29

Kusumawati, A., T.A. Wanahari, R.F. Putri, T. Untari and T. Hartati et al., 2014b. Clinical and pathological perspectives of Jembrana disease virus infection: A review. Biosci. Biotech. Res. Asia., 11: 1221-1225. DOI: 10.13005/bbra/1509
Kusumawati, A., H. Widodo, T.A. Wanahari, N. Septiana and S. Hartati, 2014c. Development of dotblot hybridization based on 522 bp repetitive sequence (R522) for detection of Toxoplasma gondii. Biosci. Biotech. Res. Asia., 11: 21-26. DOI: $10.13005 / \mathrm{bbra} / 1228$

Notomi, T., H. Okayama, H. Masubuchi, T. Yonekawa and K. Watanabe et al., 2000. Loop-mediated isothermal amplification of DNA. Nucl. Acids. Res., 28: 63-63. DOI: 10.1093/nar/28.12.e63

Parida, M., S. Sannarangaiah, P.K. Dash, P.V.L. Rao and K. Morita, 2008. Loop mediated isothermal amplification (lamp): A new generation of innovative gene amplification technique; perspectives in clinical diagnosis of infectious diseases. Rev. Med. Virol., 18: 407-421. PMID: 18716992

Soeharsono, S., N. Hartaningsih, M. Soetrisno, G. Kertayadnya and G.E. Wilcox et al., 1990. Studies of experimental jembrana disease in bali cattle. I. Transmission and persistence of the infectious agent in ruminants and gigs and resistance of recovered cattle to reinfection. J. Comp. Pathol., 103: 49-59. PMID: 2394846

Soeharsono, S., G.E. Wilcox, D.M.N. Dharma, N. Hartaningsih and G. Kertayadnya et al., 1995. Species differences in the reaction of cattle to jembrana disease virus infection. J. Comp. Pathol., 112: 391-402. PMID: 7593761

Soesanto, M., S. Soeharsono, A. Budiantono, K. Sulistyana and M. Tenaya et al., 1990. Studies on experimental jembrana disease in bali cattle. II. Clinical Signs and Haematological Changes. J. Comp. Pathol., 103: 61-71. PMID: 2394847 